Note

\section{The in Vivo Inactive Nitrate Reductase from Hansenula anomala}

\section{Nobuko Minagawa and Akio Yoshimoto}

\author{
Department of Biochemistry, \\ Niigata College of Pharmacy, \\ Niigata, Niigata 950-21, Japan
}

Received January 20, 1984

The assimilatory NAD $(\mathrm{P}) \mathrm{H}$-nitrate oxidoreductase (EC 1.6.6.2), which catalyzes the two-electron reduction of nitrate to nitrite, plays a role in the first step of nitrate assimilation in the ascomycetous yeast, Hansenula anomala ${ }^{1,2)}$ Assimilatory nitrate reductases generally contain FAD, cytochrome $b-557$, and molybdenum as prosthetic groups. ${ }^{3)}$ The isolated enzymes can exist in two interconvertible forms, active and inactive, depending on the state of the molybdenum center. ${ }^{4)}$ Inactive nitrate reductases, which can be reactivated by ferricyanide, ${ }^{3)}$ have been found in crude extracts of Chlorella vulgaris, ${ }^{5)}$ Rhodotorula glutinis, ${ }^{6)}$ Neurospora crassa, ${ }^{7)}$ and Hansenula anomala. ${ }^{2}$ The in vivo activity of nitrate reductase is also regulated by reversible interconversion between active and inactive forms. In C. vulgaris, nitrate reductase activity has been demonstrated to be regulated in vivo by bound cyanide, ${ }^{8)}$ and Solomonson and Spehar proposed a model for the cooperation of nitrate assimilation and the photosynthetic system linked through cyanide. ${ }^{9)}$

In this paper we report on the relationship between cell growth and in vivo nitrate reductase of $H$. anomala. Further, the in vivo inactive nitrate reductase is deduced not to be inactivated by cyanide, comparing with in vitro cyanide-inactivated enzyme.

Hansenula anomala strain LKBY-1 obtained from Dr. Kodama, Kodama Co., was cultivated at $30^{\circ} \mathrm{C}$ according to the method of Silver. ${ }^{11}$ The packed cells, collected by centrifugation at the indicated periods, were suspended in $3 \mathrm{vol}$ of $200 \mathrm{~mm}$ potassium phosphate buffer ( $\mathrm{pH}$ 7.4) containing $20 \mu \mathrm{M}$ FAD, $1 \mathrm{~mm}$ EDTA, $0.1 \mathrm{~mm}$ phenylmethanesulfonyl fluoride, and $0.25 \mathrm{mg} / \mathrm{ml}$ of egg white trypsin inhibitor (Boehringer), and immediately disrupted with French Press model 5501, Ohtake Works Co., Ltd. The crude homogenate was centrifuged at $15,000 \times g$ for $20 \mathrm{~min}$; the supernatant fraction was used as the crude extract, and assayed for NADPH-nitrate reductase activity and protein (Fig. 1). Crude extracts of 15 - and 20-hrold cells were further purified to obtain the preparations of "cyanide-inactivated" and "naturally inactive" enzyme, respectively, used for the experiments shown in Tables I and II.

Potassium phosphate buffer ( $\mathrm{pH}$ 7.4) containing $20 \mu \mathrm{M}$ FAD, $1 \mathrm{~mm}$ EDTA and $0.1 \mathrm{~mm}$ phenylmethanesulfonyl fluoride were used throughout the purification steps. Crude extract was fractionated by ammonium sulfate precipitation $(33 \sim 50 \%$ saturation), desalted through a Sephadex G-50 column $(4 \times 20 \mathrm{~cm})$ equilibrated with $50 \mathrm{~mm}$ buffer, and then applied on a DEAE-cellulose column (Brown, $2.2 \times 6 \mathrm{~cm}$ ) equilibrated with $50 \mathrm{~mm}$ buffer and eluted stepwise with $200 \mathrm{~mm}$ buffer. The fractions containing enzyme activity were combined and diluted to $50 \mathrm{~mm}$ phosphate concentration and applied on a DEAE Affi-Gel Blue column (Bio-Rad, $1.8 \times 3.2 \mathrm{~cm}$ ) and eluted with a linear buffer concentration gradient of from 50 to $400 \mathrm{~mm}$ phosphate $(150 \mathrm{ml})$. The final preparation (specific activity; $10.4 \mathrm{unit} / \mathrm{mg}$ ) was obtained in $25 \%$ yield.

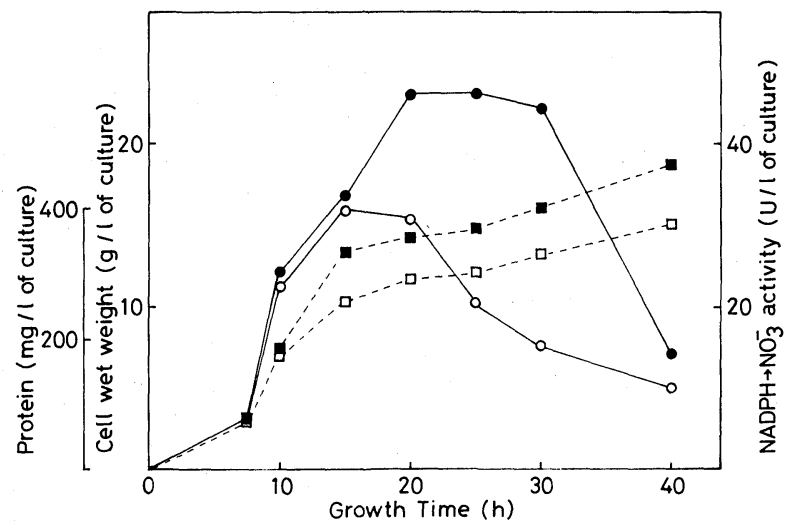

FIG. 1. The Cell Growth and NADPH-Nitrate Reductase Activity of Hansenula anomala.

a, wet weight of cells; $\square$, protein contents recovered in the crude extracts; NADPH-nitrate reductase activity estimated in the absence $(\bigcirc)$ or presence $(\bigcirc)$ of $20 \mu$ m potassium ferricyanide. All the values are expressed per liter of culture.

Abbreviation: SOD, superoxide dismutase. 
Cyanide-inactivated enzyme was prepared from the preparation containing no naturally inactive enzyme by incubation at $0^{\circ} \mathrm{C}$ for $20 \mathrm{~min}$ in the presence of $1 \mathrm{~mm}$ potassium cyanide and $0.2 \mathrm{~mm} \mathrm{NADPH}$ followed by the Sephadex G-50 gel filtration to remove excess cyanide.

Nitrate reductase activity was estimated according to our previous reports ${ }^{2,10)}$ with or without the addition of $20 \mu \mathrm{M}$ potassium ferricyanide. Protein was determined by the method of Lowry et al. ${ }^{11)}$ using bovine serum albumin as a standard. Superoxide dismutase (SOD) from bovine blood was purchased from Sigma.

Figure 1 shows the cell growth and NADPH-nitrate reductase activity of $H$. anomala. The cell growth was very active until $15 \mathrm{hr}$ and then the growth rate decreased significantly. Although the data are not shown, the estimation of cell growth by turbidity at $600 \mathrm{~nm}$ demonstrates that this organism multiplies logarithmically until $8 \mathrm{hr}$. The increase of protein content recovered in the crude extracts closely resembles cell growth. NADPH-nitrate reductase activity determined without ferricyanide which demonstrates the amount of in vivo active nitrate reductase activity, had a peak at $15 \sim 20 \mathrm{hr}$. As reported for $N$. crassa ${ }^{7}$ it is suggested that the activity of assimilatory nitrate reductase in vivo is closely involved in the cell growth. On the other hand, NADPH-nitrate reductase activity estimated in the presence of added ferricyanide which demonstrates the total amount of nitrate reductase, both active and inactive, reached a maximum during $20 \sim 30 \mathrm{hr}$. Therefore, the amount of inactive nitrate reductase alters with the cell growth stage similar to $N$. crassa. ${ }^{7)}$ Although the data are not shown in Fig. 1, the behavior of reduced methyl viologen-nitrate reductase activity closely resembles that of NADPH-nitrate reductase activity. The total amount of activity seems to reflect the enzyme protein synthesis and degradation, whereas inactive nitrate reductase is suggested to result from different short-term regulation.

Table I shows the effect of oxygen on the reactivation process by ferricyanide of naturally inactive and cyanideinactivated enzymes. In anaerobic conditions, there observed no activation of naturally inactive enzyme by the addition of ferricyanide. On the other hand, cyanideinactivated enzyme was reactivated similarly under both aerobic and anaerobic conditions, which is in good agreement with the results reported by Jawali and Sane. ${ }^{12)}$ Quite similar results to Table 1 were obtained under anaerobic conditions with the addition of glucose oxidase, glucose, and catalase to the main compartment instead of palladium catalysts. These results demonstrate that the effect of oxygen differs between the two inactive enzymes. Similar experimental results were obtained with the enzyme from $N$. crassa (unpublished data).

Table II shows the effect of SOD on the reactivation process by ferricyanide. Without ferricyanide, SOD exhibits no effect on either enzymes. SOD seems to have a inhibitory effect on the reactivation of naturally inactive enzyme. Although the data are not shown, SOD exhibited

\section{TABLE I. EFfects Of OXYGEN ON THE REACTIVATION BY FerRicyanide of Naturally INACTIVE AND CyANIDE-INACTIVATED ENZYMES}

Warburg vesssels equipped with two side arms were used. The main compartment of the vessel received $0.8 \mathrm{ml}$ of a mixture containing $50 \mu \mathrm{mol}$ of potassium phosphate buffer (pH 7.4), $20 \mu \mathrm{mol}$ of potassium nitrate, $0.4 \mathrm{mg}$ of bovine serum albumin (Sigma, fraction V), $10 \mathrm{nmol}$ of $\mathrm{FAD}$, and nitrate reductase $(6.2 \mu \mathrm{g}$ of naturally inactive enzyme or $3.5 \mu \mathrm{g}$ of cyanide-inactivated enzyme). Ferricyanide $(0.1 \mathrm{ml}, 20 \mathrm{nmol})$ was placed in the first side arm, and NADPH $(0.1 \mathrm{ml}, 0.2 \mu \mathrm{mol})$ in the second side arm, and the center well received a few grains of palladium catalyst (BBL). The gas phase was pure hydrogen or air as indicated. After pre-incubation for $10 \mathrm{~min}$ at $30^{\circ} \mathrm{C}$, ferricyanide was added, following by incubation for $10 \mathrm{~min}$. The reaction was started by the addition of NADPH under aerobic conditions. NADPH-nitrate reductase activity was determined as previous report. ${ }^{2,10}$

\begin{tabular}{cccc}
\hline Atmosphere & $\begin{array}{c}\text { Ferricyanide } \\
(20 \mu \mathrm{M})\end{array}$ & $\begin{array}{c}\mathrm{NADPH} \rightarrow \mathrm{NO}_{3}{ }^{-} \\
\text {Naturally } \\
\text { inactive }\end{array}$ & $\begin{array}{c}\text { (unit/mg) } \\
\text { Cyanide- } \\
\text { inactivated }\end{array}$ \\
\hline Air & + & 8.60 & 7.11 \\
$\mathrm{Air}$ & - & 5.81 & 1.92 \\
$\mathrm{H}_{2}$ & + & 6.02 & 5.85 \\
$\mathrm{H}_{2}$ & - & 5.53 & 1.59 \\
\hline
\end{tabular}

TABLE II. EFfects OF SOD ON THE

Reactivation by FerRicyanide

of Naturally INACTIVE AND

CYANIDE-INACTIVATED

ENZYMES

The naturally inactive enzyme $(2.4 \mu \mathrm{g})$ or cyanideinactivated enzyme $(0.7 \mu \mathrm{g})$ were pre-incubated at $30^{\circ} \mathrm{C}$ for $10 \mathrm{~min}$ with the indicated additions and assayed for NADPH-nitrate reductase activity. The values shown here are the average of three experiments.

\begin{tabular}{cccc}
\hline $\begin{array}{c}\text { Ferricyanide } \\
(20 \mu \mathrm{M})\end{array}$ & $\begin{array}{c}\mathrm{SOD} \\
(0.1 \mathrm{mg} / \mathrm{ml})\end{array}$ & $\begin{array}{c}\mathrm{NADPH} \rightarrow \mathrm{NO}_{3}{ }^{-} \\
\text {Naturally } \\
\text { inactive }\end{array}$ & $\begin{array}{c}\text { (unit/mg) } \\
\text { Cyanide- } \\
\text { inactivated }\end{array}$ \\
\hline- & + & 6.08 & 1.96 \\
- & - & 5.99 & 1.89 \\
+ & + & 6.29 & 6.60 \\
+ & - & 7.68 & 5.76 \\
\hline
\end{tabular}

no effect when it was added after the initiation of the NADPH-nitrate reduction, the addition of NADPH, indicating that SOD has no effect on the activity assay system and exerts the inhibitory effect shown in Table II during the pre-incubation time with the enzyme and ferricyanide. On the other hand, SOD, at the same time, 
showed a stimulatory effect on the reactivation of cyanideinactivated enzyme by ferricyanide. This phenomenon also could be observed only when SOD was added with the enzyme together with ferricyanide during the preincubation time, which is quite similar to the inhibitory effect on naturally inactive enzyme.

Consequently, it is suggested that superoxide anion was generated during the pre-incubation of both inactive enzymes with ferricyanide, and was involved in the reactivation process in different manners. Although the data are not shown, under anaerobic conditions there observed no effect of SOD as was expected. Therefore, from Table I and II, in the reactivation process of naturally inactive enzyme, superoxide anion must be generated from oxygen, and is involved in the reactivation mechanism, whereas in the case of cyanide-inactivated enzyme, superoxide anion seems to have a somewhat inhibitory effect on the reactivation process by ferricyanide. At present, the exact mechanism of the involvement of superoxide anion is unknown, however, it is at least concluded that the in vivo inactive nitrate reductase of $H$. anomala is not formed by binding with cyanide, and that this organism is deduced to have a different regulatory mechanism from that of $C$. vulgaris. ${ }^{8,91}$

Acknowledgment. The authors thank Dr. Kodama, Kodama Co., for the gift of the strain LKBY-1 of $H$. anomala .

\section{REFERENCES}

1) W. S. Silver, J. Bacteriol., 73, 241 (1957).

2) N. Minagawa and A. Yoshimoto, Agric. Biol. Chem., 47, 125 (1983).

3) E. J. Hewitt and B. A. Notton, "Molybdenum and Molybdenum-Containing Enzymes," ed. by M. P. Coughlan, Pergamon Press, Oxford, 1980, pp. $273 \sim 325$.

4) M. A. De La Rosa, C. Gomez-Moreno and J. M. Vega, Biochim. Biophys. Acta, 662, 77 (1981).

5) B. Vennesland and C. Jetschmann, Biochim. Biophys. Acta, 227, 554 (1971).

6) M. G. Guerrero and M. Gutierrez, Biochim. Biophys. Acta, 482, 272 (1977).

7) N. Minagawa and A. Yoshimoto, Agric. Biol. Chem., 47, 2661 (1983).

8) G. H. Lorimer, H. S. Gewitz, W. Völker, L. P. Solomonson and B. Vennesland, J. Biol. Chem., 249, 6174 (1974).

9) L. P. Solomonson and A. M. Spehar, Nature, 265, 373 (1977).

10) N. Minagawa and A. Yoshimoto, J. Biochem., 91, 761 (1982).

11) O. H. Lowry, N. J. Rosebrough, A. L. Farr and R. J. Randall, J. Biol. Chem., 193, 265 (1951).

12) N. Jawali and P. V. Sane, FEBS Lett., 158, 213, (1983). 